\title{
The economic effects of regional shopping centres
}

Received (in revised form): 23 March 2007

\section{John Robertson}

is the Head of the Economics \& Research group within Nathaniel Lichfield \& Partners Ltd. He has worked in university research roles, planning consultancy and government bodies in the UK and overseas over the last 30 years and is responsible for economic studies of many major developments such as the new Wembley Stadium, regional shopping centres, airports, universities and theme parks.

\section{James Fennell}

is Managing Director of Nathaniel Lichfield \& Partners Ltd and has extensive experience of retail and town centre development projects for a wide range of private sector clients including developers, retailers and investors. He has advised on the MetroCentre in Gateshead and Lakeside in Thurrock for many years as well as many major city and town centre redevelopment projects, including schemes for Oxford, Newcastle-upon-Tyne, Peterborough and Bromley.

\begin{abstract}
Regional Shopping Centres (RSCs) have long been perceived as having negative effects on the shopping hierarchy and unpopular with Government, a view not necessarily based on hard evidence. This paper examines the positive and negative effects of a number of such centres based on a series of research studies undertaken for developer Capital Shopping Centres. The employment, labour market and expenditure benefits of these developments to local and regional economies are assessed. Wider impacts in terms of attracting new investment to an area, linkages with tourism and physical regeneration of derelict areas are also examined. In addition, the social impacts these centres have on local communities are examined. At the same time, potential adverse effects on surrounding town centre shopping facilities are investigated through analysis of a range of indicators of town centre vitality and viability, and discussions with town centre managers. The possible future direction for such centres is also considered in the light of Government planning policy, which could lead to the emergence of RSCs as focal points for sustainable new mixed use communities.
\end{abstract}

John Robertson Nathaniel Lichfield \& Partners Ltd 14 Regent's Wharf All Saints Street London N1 9RL, UK Tel: +44 (o) 2078374477 Fax: +44 (o) 2078372277 E-mail: london@nlpplanning.com Web: www.nlpplanning.com

\section{Keywords:}

regional shopping centres (RSCs), economic impact, regeneration

Journal of Retail and Leisure Property (2007) 6, 149-170. doi:10.1057/palgrave.rlp.5100057 


\section{INTRODUCTION}

Regional shopping centres (RSCs) have been much maligned by the Government and press over the last 20 years. While highly successful in retail terms and popular with consumers, shifts in Government retail planning policy since the early 1990s have moved against them, largely reflecting aims to support town centres and reduce car travel. Yet there has been very little considered research on the economic impacts of these developments. Opinions and changing policies have often been formulated against the background of anecdotal evidence of their negative effects and shifts in the general thinking behind Government policy.

This paper examines these issues, drawing on a series of research studies carried out by Nathaniel Lichfield \& Partners and the Oxford Institute of Retail Management on behalf of Capital Shopping Centres, an owner and developer of these regional schemes. These studies examined the economic impacts of four centres - the MetroCentre in Gateshead, Lakeside in Essex, the Braehead Centre in the west of Scotland and the Cribbs Causeway centre to the north of Bristol. Where information is available, experience at other RSCs, such as Merry Hill in Dudley, Meadowhall in Sheffield and Bluewater Park in Kent, is also drawn upon.

\section{WHAT ARE THEY?}

Government Guidance in PPS6 defines RSC as 'out-of-town shopping centres which are generally over 50,000 square metres gross retail area, typically comprising a wide variety of comparison goods stores'. The four shopping centres on which this research focuses meet these criteria:

1. The MetroCentre (Figure 1) with $165,360 \mathrm{~m}^{2}$ of mainly comparison retail floorspace in 325 retail units including two department stores. ${ }^{1}$

2. Lakeside with $125,000 \mathrm{~m}^{2}$ spread over 320 retail units including two department stores. ${ }^{2}$

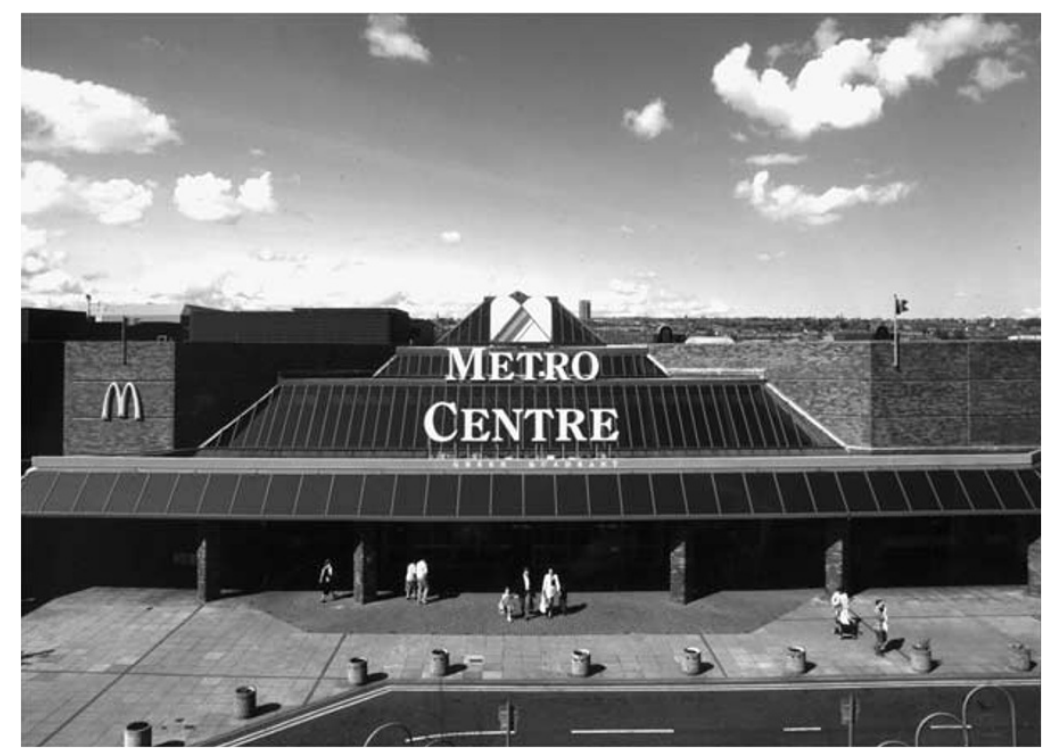

Figure I: MetroCentre regional shopping centre, Gateshead 
3. The Braehead Centre (Figure 2) with $55,000 \mathrm{~m}^{2}$ in 110 retail units including two department stores. ${ }^{3}$

4. The Mall at Cribbs Causeway with $69,680 \mathrm{~m}^{2}$ in 135 retail units including one department store. ${ }^{4}$

The difference between RSCs and other centres is, however, not merely one of size. Key characteristics include the range, style and selection of goods and services, the physical form and the broad offer under a single roof, the location and the type of accessibility. High profile, landmark buildings combined with high levels of car parking, but also good public transport are also typical - the MetroCentre, like Meadowhall, is served by a railway station as well as its own bus station (Figure 3). RSCs function differently from other centres by drawing from a wider catchment area, drawing a different sort of shopping trip, for example 'for a day out' or 'for something special'. Often trips to such centres are more 'leisurely' shopping trips. 5

Most regional centres include, or are co-located with, major leisure and catering elements, typically a multiplex cinema, ten-pin bowling facilities and a range of cafes/restaurants. Braehead has an ice rink, a curling rink, a sporting events arena and conference facilities and adjoins a Snowdome.

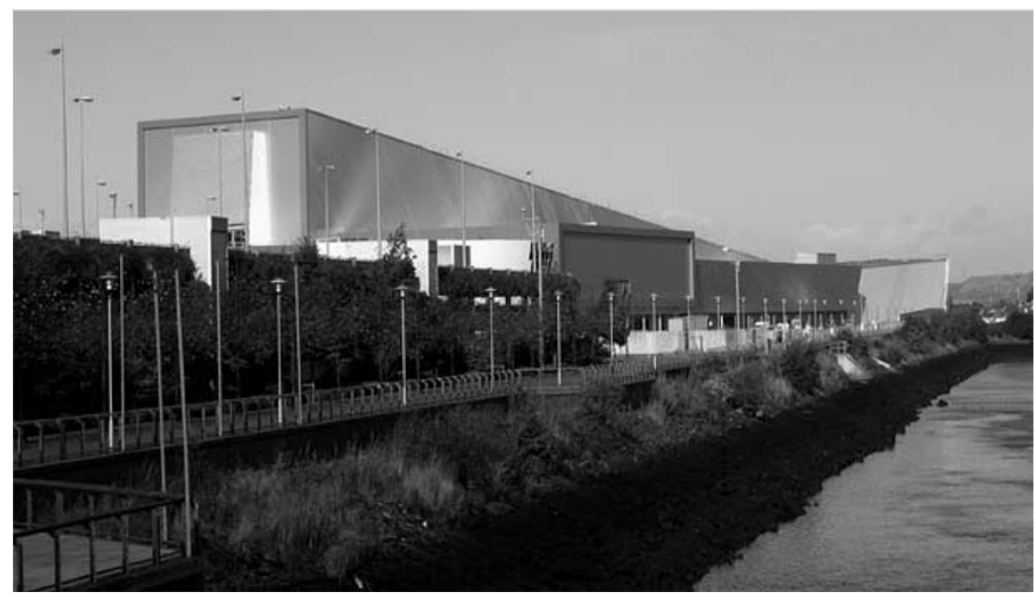

Figure 2: Braehead Shopping Centre, Renfrewshire

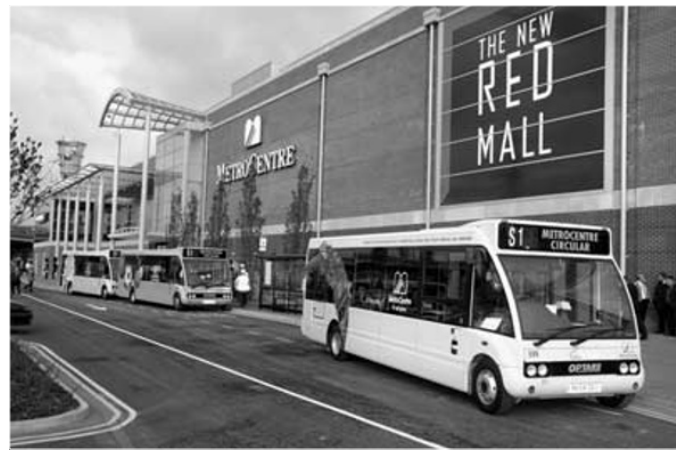

Figure 3: MetroCentre Shopping Centre, Gateshead showing circulating bus service around the site 
Their high visitor numbers demand locations adjoining strategic roads Lakeside beside the M25, Braehead on the M8, MetroCentre near the $\mathrm{A} 1(\mathrm{M})$ and Cribbs Causeway close to the M4/M5 junction.

This combination of factors means that the 'offer' of RSCs is perceived differently by customers from that of other types of centres, and they draw consumer spending from beyond their immediate geographical areas. Various studies have demonstrated that RSCs do make a different contribution to a region from other types of centres, and that customers recognise and value this. ${ }^{6}$

\section{EVOLUTION}

RSCs are just one element of the restructuring of retail provision which has taken place over the last 30 years in the UK and elsewhere as retail innovation took place to service the needs of increasingly affluent and mobile consumers. UK retailing has changed and continues to change in terms of the goods offered, the styles and locations of stores and centres built, and the size and organisation of retail companies.

The development of RSCs reflects several broad shifts in retailing. First, purpose-built shopping centres were built, both within traditional centres or in more free-standing locations, and of different scales but providing a different shopping experience for the consumer. Secondly, some polarisation of shopping occurred, with consumers preferring to shop in larger centres with a wide range of stores and services, or in smaller, attractive, focused and convenient centres. ${ }^{7}$

Supermarkets also began opening extensive, single-level, but standalone out-of-town stores. These were followed by retail warehouses, initially called 'bulky goods' retailers, for whom town centre locations were considered inappropriate, offering electrical goods, furniture and carpets, and clustered in a retail park formation. The mid-1980s saw a third wave of decentralisation involving town centre comparison goods outlets. Because of the nature of such businesses, large-scale clustering was an inevitable consequence.

Retailers began to rely upon widespread growth in car ownership to permit the concentration of demand in new locations and the most accessible locations for car-borne consumers proved to be edge-of-town or wholly out-of-town. Such sites were also less complex to assemble, construction and maintenance costs were lower, and larger and more modern premises could be developed than was immediately possible in existing town or city centres. Such growth was facilitated in the 1980s by a more laissez faire government attitude towards development of this kind. ${ }^{8}$ Although planning policy subsequently re-asserted itself in defence of existing town and city centres, by 2000 , there were ten regional-scale centres of more than $50,000 \mathrm{~m}^{2}$ in out-of-town locations in the UK.

It is notable that the majority of RSCs were granted planning permission by the Government of the day, although often after public inquiries or other protracted planning processes. An exception was the MetroCentre that did not require planning permission as it lay within an Enterprise Zone. Key factors that supported approval of the Lakeside and Braehead centres were their potential role as catalysts for regeneration of 
run-down areas, and their substantial job creation, while their forecast retail impacts were considered acceptable. While regeneration was less of an issue for Cribbs Causeway, that scheme was seen as likely to confer advantages in competition and shopping quality to the shopping public without significant harm to other retail centres or regeneration aims. ${ }^{9}$

Once developed, the out-of centre shopping centres did not remain static. Reflecting changing patterns of consumer behaviour, the centres themselves changed and developed to become locations well served by public transport, with a mix of food and non-food retail provision as well as other services. ${ }^{10}$

\section{CAPITAL INVESTMENT}

The development of such RSCs often brought substantial private sector capital investment to areas that had previously attracted little. Investment not only meant new buildings but also significant improvements to an area's infrastructure. The construction of the Cribbs Causeway Mall, for example, brought an initial $£ 200$ m of capital investment, $£ 20 \mathrm{~m}$ more in the adjoining Venue leisure facility, and a further $£ 10 \mathrm{~m}$ to upgrade junction 17 of the M5 motorway and construct a dual carriageway linking it with the A38. Similarly, some $£ 500 \mathrm{~m}$ was invested in the development of the Braehead Centre and related facilities, including a new M8 junction, improvements to nearby roads, a new public park and riverside walkway.

Such investment has been ongoing as the shopping centres are extended or refurbished, shop units are refitted or enhanced, or surrounding infrastructure is upgraded. Over the last five years, some $£ 112 \mathrm{~m}$ of further capital investment has been made in the MetroCentre by its owners, including $£ 85 \mathrm{~m}$ for the development of a new Red Mall extension and a further $£ 38 \mathrm{~m}$ is to be invested over the next five years, including a new bus station. At the Braehead Centre, a further $£ 25 \mathrm{~m}$ of investment is anticipated over the next five years, on infrastructure, land remediation and other improvements.

The construction stages of the RSCs have themselves had significant economic impact. Construction-related employment for the initial development of the Braehead Centre, for example, is estimated to have reached 2,500 jobs. ${ }^{11}$ This was a substantial source of local jobs over a period of several years in an area of high employment. While these initial jobs were temporary, some work of this nature tends to be ongoing at the centres over time, and jobs continue to be supported in refitting of retail units and ongoing maintenance of buildings.

\section{EMPLOYMENT EFFECTS}

Turning to more permanent effects, there is little doubt that RSCs are major generators of employment. Total job numbers based on site range from 4,300 at Braehead to almost 11,000 at the MetroCentre in Gateshead (Table 1) while Merry Hill is estimated to support 6,000 jobs. ${ }^{12}$ These numbers exclude significant levels of additional seasonal employment, primarily over the Christmas/New Year period which can increase normal 
Table I: Gross employment within regional shopping centres

\begin{tabular}{llll}
\hline Centre & $\begin{array}{l}\text { Total permanent jobs based } \\
\text { at centre }\end{array}$ & Seasonal jobs & Total FTE jobs \\
\hline Braehead Centre & 3,600 & 720 & 2,980 \\
Cribbs Causeway & 5,950 & 1,430 & 4,750 \\
Lakeside & 6,500 & 1,660 & 4,590 \\
MetroCentre & 8,000 & 2,960 & 7,490 \\
\hline
\end{tabular}

Source: CSC, 2005. Note: I part-time $=0.5$ FTE job and I seasonal job $=0.1$ I FTE job

employment levels by up to 35 per cent. This level of employment in a single development is broadly equivalent in scale to a major inward investment such as a car manufacturing plant.

Other than the seasonal jobs available, almost all the jobs based in these centres are permanent. In common with the retail sector nationally, a relatively high proportion are part-time and across the four centres examined the proportion of permanent employees who work part-time ranges from 57 to 65 per cent. This proportion also partly reflects these centres' long opening hours and the fact that they typically operate seven days a week. Again, as in retailing nationally, the majority (70 per cent) of employees at the centres tend to be female and the centres are an important source of local job opportunities for women.

An estimated 75-80 per cent of all employees within the centres are sales and customer interface staff including those in catering outlets. A range of other occupations, however, are also present, typically store management (about 8 per cent of jobs), supervisors ( 9 per cent), clerical/ administration ( 3 per cent), centre management ( 1 per cent), centre maintenance/cleaning ( 2 per cent) and centre security ( 1 per cent). ${ }^{13}$

\section{INDIRECT EMPLOYMENT}

Further jobs are supported by these shopping centres in the form of 'indirect' employment arising from the spending of individual businesses located there on goods, supplies and services from firms within the local and regional economies. In addition, 'induced' employment is supported in other local shops and services through the spending of wages by shopping centre-based employees as well as by wage spending of employees in the supplier firms that serve the centre. Collectively these are commonly known as 'multiplier' effects.

Although there is little research in this area, indications are that the local indirect employment effects of retail developments are generally less significant than some other forms of development, such as manufacturing, but similar to other service sectors. This is partly because national retailers tend to obtain goods centrally through their UK headquarters, or from national or regional distribution centres, rather than at a local level. Some retailers at the RSCs do, however, sell goods produced locally, while services such as cleaning, security, waste disposal and landscaping are almost wholly dependent on local firms. In addition, the RSCs' management companies tend to spend significant amounts with local suppliers. ${ }^{13}$ 
Table 2: Total employment related to regional shopping centres

\begin{tabular}{lllll}
\hline Centre & $\begin{array}{l}\text { Total jobs based at } \\
\text { centre }\end{array}$ & $\begin{array}{l}\text { Visitor-related } \\
\text { jobs }\end{array}$ & $\begin{array}{l}\text { Indirect/induced } \\
\text { jobs }\end{array}$ & Total \\
\hline Braehead Centre & 4,320 & 200 & 950 & 5,470 \\
Cribbs Causeway & 6,380 & 100 & 970 & 7,450 \\
Lakeside & 8,160 & $390-600$ & $1,000-1,040$ & $9,550-9,900$ \\
MetroCentre & 10,960 & $290-425$ & $580-600$ & $11,830-11,985$ \\
\hline
\end{tabular}

Source: CSC/NLP surveys

The extent of such multiplier employment also reflects factors such as the level of employee wage spending and how much is retained in the local area. While average retail wage levels are not high compared to some other sectors, a high proportion of wage spending is likely to be captured locally as most shopping centre staff tend to live nearby. ${ }^{14}$ Based on research elsewhere, and the economic characteristics of each centre and its local economy, an estimated 20-30 additional multiplier jobs are supported for every 100 directly employed at a RSC.

Further employment is related to the expenditure of visitors to the RSC but takes place outside it. This involves jobs in buses and taxis, petrol filling stations, hotels, other nearby shops and restaurants and bars, any of which were used or visited partly or wholly as a consequence of a shopping trip to the RSC. Based on conservative estimates of visitor spending to and from the centre, the level of such jobs is comparatively low but can amount to several hundred. Table 2 illustrates the significant levels of such multiplier and other indirect employment in the local economy.

\section{JOB DISPLACEMENT}

A frequently raised criticism is that new jobs in these centres are simply transfers from other existing retail centres, that is job displacement. Some retail developments can have relatively high local displacement effects, up to 50 per cent of the new jobs provided. ${ }^{15}$ There are certainly indications that such effects occurred initially with several of the RSCs. In relation to the MetroCentre, between 1984 and 1991 retail job losses in Tyne \& Wear districts excluding Gateshead were almost 18 per cent (5,500 jobs), compared with declines of 3.4 per cent regionally and 6.3 per cent nationally. When the Braehead Centre first opened, some 15 per cent of the initial 3,600 new jobs at the Braehead Centre in 1999 were reported to be filled by retailers transferring staff from other stores in the general area. However, 24 per cent were students or school leavers, 2 per cent were labour-market returners and 9 per cent were previously unemployed. ${ }^{16}$

Since then, however, there has been significant growth in retail employment nationally, which in many cases has offset or outweighed any initial job losses in nearby centres. Any initial job displacement that did occur can be argued as having reduced over time due to factors such as new retail development in adjoining districts stimulated by the RSCs leading to job growth above the national rate in some areas. If the RSCs 
had not been developed, it is probable that retail development would have taken place elsewhere in their regions to accommodate retail spending growth. Some of this development may have taken place in surrounding centres or out-of-centre schemes, but may also have occurred outside the region and it is not clear that an equivalent amount of development would have occurred. This makes it difficult to quantify what level of continuing job displacement the RSCs have had. On balance, while displacement at some centres may have reached 30-40 per cent initially this has been diluted greatly over time so that any ongoing effects are probably below 10 per cent.

Any such job displacement also needs to be put into context. In many other sectors of the economy, jobs created in one place are often at the expense of jobs elsewhere. This is not a reason for valuing them any less since the new jobs may reflect productivity improvements or result in higher quality jobs than those being replaced. This factor is a normal part of a dynamic economy that has helped create a substantial number of new jobs within regions as a whole.

It is clear that the RSCs were able to capture, within their local area, a substantial share of the retail spending growth, and consequent retail employment growth, which occurred during the 1980s and 1990s. Some of these jobs may reflect displacement of retail jobs that would have occurred anyway in the local area, but this is by no means certain. Therefore, a high proportion of employment created by the RSCs can be considered to be net additional jobs to the local area as a result of the large amount of retail expenditure concentrated at their location, rather than just redistribution of retail employment from elsewhere.

\section{IMPACTS ON LOCAL LABOUR MARKETS}

The jobs created by RSCs are important to the local labour market. As an indication of their overall importance, the 3,600 direct Braehead Centre jobs accounted for nearly 5 per cent of all employee jobs based in the local district of Renfrewshire in 2003.

The other noticeable feature of the jobs provided by the RSCs is that they are filled primarily by local residents. For example, almost half the jobs based at the MetroCentre are held by residents of the local borough of Gateshead, and almost 80 per cent of employees live within Tyne \& Wear. Similar patterns apply at the other centres. Some 95 per cent of Braehead employees live within the two districts that the centre straddles. ${ }^{17}$ Again, nearly 80 per cent of Cribbs Causeway's retail staff live within the two immediately adjoining districts.

Although 60 per cent or so of the jobs are part-time opportunities, this partly reflects the nature of retail jobs generally and the centres being open for long hours. There is no indication that the regional centres have created an over-representation of part-time jobs in local areas. Taking the MetroCentre as an example, between 1984 and 2002, part-time jobs in Tyne \& Wear increased from 23 to 30 per cent of all jobs, while in Gateshead the increase was from just over 19 to 29 per cent. Over the same period, part-time employment nationally increased from 22 to 32 
per cent of the workforce, suggesting that the pattern in Gateshead is in line with regional and national trends.

The types of employment provided are important locally since they provide flexible working arrangements. The importance of these types of jobs is also confirmed by the 1997 Labour Force survey, which found that 79 per cent of female part-time employees would not wish to work full-time. ${ }^{18}$ Experience at several of the regional centres has been such that flexible jobs are particularly important to and sought by:

1. students and others who wish to combine work with training or education

2. those looking after children, particularly single parents or where one parent is already in full-time employment

3. those seeking second jobs as an extra source of income

4. early retirers who wish some part-time work for social rather than income reasons and

5. those seeking a different balance between work and family life or other personal commitments.

The research also suggests that retail jobs of the type offered at RSCs are often perceived as attractive, especially among the young as many shops in these Centres are oriented towards younger customers. These jobs can act as a way of gaining experience to allow progression to more senior roles in retailing in due course. Indeed, many of the jobs available are entry-level jobs and typically attract enquiries from 16 to 20 year olds. There are, however, indications of greater efforts to recruit older people to provide a more balanced workforce.

The accessibility of jobs for local people is often aided by a job recruitment centre located within the shopping centre. The Braehead Centre deals with approximately 200 job enquiries weekly and typically fills 1,000 vacancies each year. A significant proportion of these are from Renfrewshire and Glasgow residents, suggesting that the nature of the jobs available is consistent with many of the types of jobs sought within the local labour market. ${ }^{19}$ At the MetroCentre, the accessibility of these jobs is complemented by the Metrojobs and MetroPeople employment initiatives. The former offers work skills training to local residents, while the 'Metrojobs' job centre helped 2,000 people into jobs within its first two years of operation. ${ }^{20}$

There is also some evidence that the RSCs have contributed to relatively low unemployment levels in their local areas. This could reflect the range of jobs available that provide job opportunities at skill levels prevalent among claimant unemployed workers which typically contain high proportions of lower skilled residents. Prior to the Lakeside Centre's opening, the Thurrock area had been suffering from very high structural unemployment and declining industrial sectors and badly needed large numbers of jobs. The effect of Lakeside on local labour markets is illustrated by Figure 4 and Thurrock Council's analysis of employment trends:

'Throughout the 1980s, unemployment comfortably exceeded the national average with consistent double figure rates. The $1990 \mathrm{~s}$ 


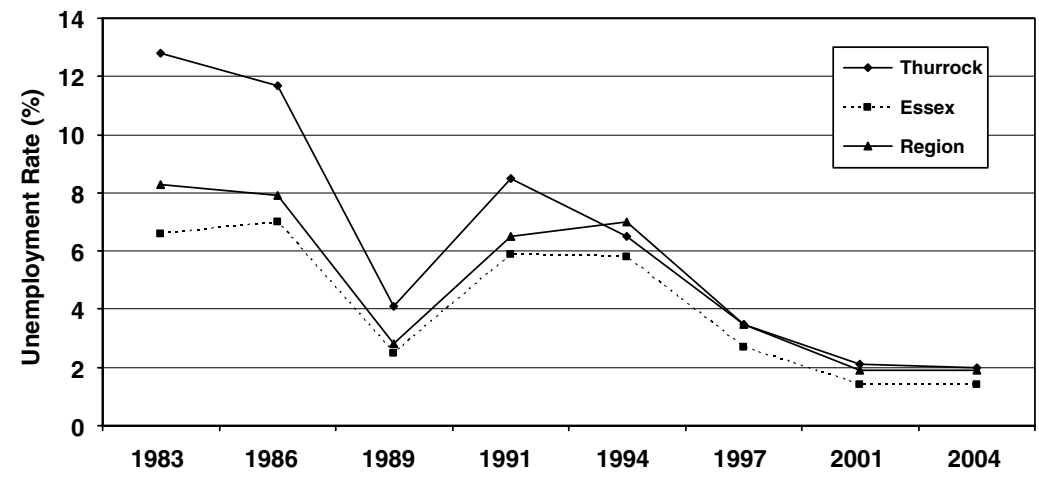

Figure 4: Unemployment change in Thurrock 1983-2004

Source: Nomis, Essex County Council

brought Lakeside and a significant downward shift in unemployment to parity with national figures.... Thurrock has now entered a historic period characterised by unemployment not only substantially below national figures but also lower than regional or County figures. ${ }^{21}$

A similar picture is evident at Braehead. In 1994, the claimant unemployment rate in Renfrewshire was 8.1 per cent, slightly above the Scottish average of around 7.6 per cent. By 2005, the unemployment rate in Renfrewshire had fallen to achieve parity with the national rate of 2.8 per cent.

It is also worth noting that, over the last ten years or so, retailing has been a relatively stable sector less vulnerable to economic downturns, and can contribute to greater resilience in a local economy. This is especially important in regeneration areas that tend to be still over-reliant on declining sectors and there is now much stronger competition for high job-creating, knowledge-based inward investments from other parts of the UK and the enlarged European Union.

\section{CONTRIBUTION TO REGENERATION}

It was in the hope of stimulating regeneration that several of the RSCs were allowed in the first place, even at a time when the tide had started to turn against out-of-centre retail developments. At Lakeside, Thurrock Council supported a major shopping centre scheme specifically because it would create 4,000 jobs and act as a catalyst for the regeneration of the area. For Braehead, one of the reasons given by the Secretary of State in allowing the centre on appeal was its role in 'restoring and making positive use of a large unused site, largely through private investment, that would otherwise be unlikely to be achieved in the near future without considerable public expense'. The MetroCentre was supported by the local authority at the outset because of its potential benefit to the local economy and increased job opportunities. ${ }^{22}$

In this context, a key feature of a number of RSCs was that they were built on unattractive brownfield land in locations that had for a long period failed to attract new investment or regeneration and often had high remediation and development costs. The site of the MetroCentre complex 


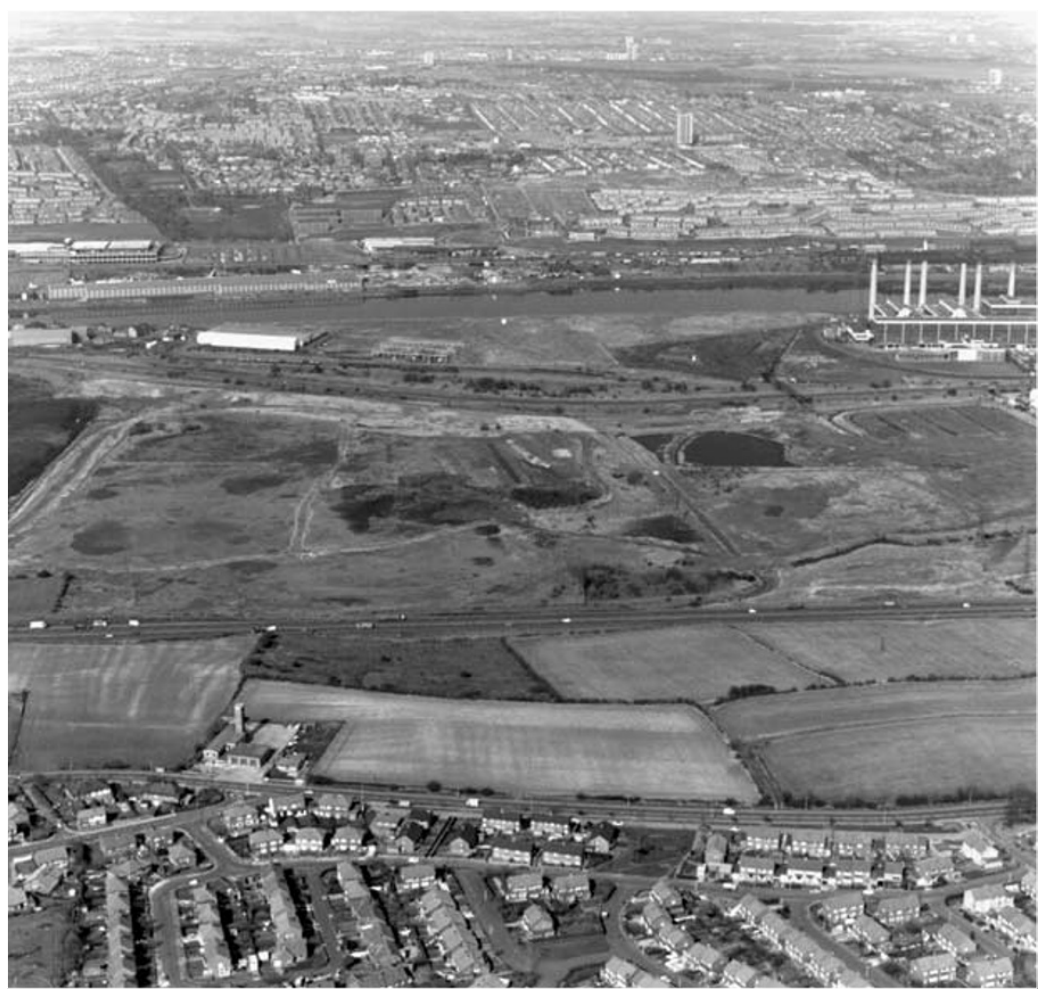

Figure 5: Previously derelict site of MetroCentre regional shopping centre

was previously a waterlogged ash dump for Dunston Power Station on the banks of the Tyne (Figure 5). The Lakeside and Bluewater Park sites were former chalk quarries that had failed to attract development interest for many years. Braehead was also an environmentally unattractive site, part of a derelict power station with a line of high electricity pylons running through it and was also part of an extensive area of partly derelict former industrial land running along the south bank of the River Clyde that had been vacant for almost 30 years. While other more central parts of Glasgow's riverfront had been the focus for regeneration initiatives, this area had been shown little interest.

To a large extent it was the high land values generated by retail uses that made development of these sites viable and attractive when no interest had been shown by other land uses. Such uplifts in value were necessary where very high site remediation was required, where development costs and developer risk were generally high and where extensive new transport infrastructure had to be funded. For Lakeside, the construction of the M25 motorway during the mid-1980s increased the attractiveness of that area to retail development but what was permitted was partly on the basis that a large retail scheme would fund a desired link road for the area.

Even so, the main stimulus for developing the MetroCentre was the site's designation within one of the UK's first Enterprise Zones, designed by central government to provide incentives for development in declining areas. This made the area especially attractive for retail development, 
with 100 per cent tax allowances against capital expenditure, no rates payable for ten years and no requirement for planning permission for non-food retail development. ${ }^{23}$

Against this background, there is little doubt that the RSCs initiated major change to the image and perception of local areas. They brought high-quality landmark buildings and facilities to areas that had attracted little in the past. They helped clean up and landscape formerly derelict areas. They substantially improved local infrastructure, public transport and general accessibility of the surrounding area.

The extent to which such change in the image of an area has influenced subsequent investment decisions is difficult to estimate. Research on the role of flagship developments on regeneration has accepted that such schemes can transform their areas by their own presence and through the additional investment and consumption they attract. Successful flagship schemes have been shown to help market an area, and reposition it in cultural and geographic terms. ${ }^{24}$ It seems likely that the development of the new shopping centres helped promote the local areas as locations conducive to further investment.

The effect is perhaps seen most clearly in Gateshead. Prior to the MetroCentre development in the mid-1980s, the area was stigmatised in investment terms and held an image associated with the legacy of its industrial past. At the time, the MetroCentre, along with the Nissan car plant, were seen as the only beacons of light after the severe recession in the early 1980s, and as the first signs of emerging hope and confidence in the region:

'Around 1986 the Tyne \& Wear economy stopped declining precipitately and since then it has followed a new, more positive track. The reasons for this stabilisation of the local economy are numerous. Three big factors were the end of shipbuilding as a drag on the local economy [equivalent to -3000 jobs per annum], the opening of Nissan [ +5000 jobs] and the opening of the MetroCentre $\left[+6000\right.$ jobs]. ${ }^{24}$

In this context, the scale and scope of the development at the MetroCentre appeared to give a renewed identity to Gateshead, an impact magnified by the fact that it was the first RSC of its type in the UK. The available evidence suggests that this initial development helped stimulate new retail and leisure, and more recently office, investment in the immediate area.

The Braehead development brought forward regeneration of its local area by many years. While considerable development activity and regeneration programmes are now taking place along parts of the River Clyde, much of this has been fairly recent, with most focused on the Glasgow stretch of the river and involving high levels of public sector funding. It is probable that such regeneration interest would eventually have reached as far west as the Braehead site if the Shopping Centre had not been developed, but it is not clear how long this would have taken. The new shopping centre provided a focal point and the initial stimulus that sparked off development activity in this relatively neglected area, and without drawing on the limited public sector regeneration funding that needed to be spread over a very large area of Clydeside. 
The development of Lakeside and its associated retail park has been acknowledged by Thurrock Council as the most prominent economic development initiative in stimulating the regeneration of that area, and reviving it from its low point. As RSCs of this scale and quality were still a major innovation at the time, and this was the first one in the region, the establishment of Lakeside helped change the image of the area and put Thurrock on the map to a much greater extent. Given the large scale of the investment involved, it also sent out a strong message of investor confidence in the area. A report by the Council's economic development department notes that:

'This deliberate diversification of the local economy brought a real paradigm shift for Thurrock generating extensive jobs and fundamentally reprofiling the labour market.... Indeed the image change brought by Lakeside in many ways catalysed the successful residential development of Chafford Hundred on further derelict land, which itself is bringing similar changes to Thurrock's demographic profile.'

\section{ATTRACTION OF INVESTMENT}

There is a risk for developers in investing in a new and unproven location that may not attract occupiers, especially one with a previously poor image and unattractive appearance. Few developers wish to be the first to develop where demand or occupier interest is uncertain, or where major new infrastructure has to be provided. It can often be hard, therefore, to attract the first development, but once that has come, others often follow when the scheme is seen to be successful. The RSCs appear to have played that 'first development' role, raising developer and occupier confidence in the area although clearly aided by the high values generated by retail uses. Another key factor was, however, making an area more attractive to developers through the greatly improved infrastructure and transport accessibility that had also come with the shopping centre. These factors have stimulated substantial new investment around the RSCs.

A range of other developments occurred, and are still occurring, on adjoining land after the Braehead Centre opened in 1999. These include the $£ 65 \mathrm{~m}$ XScape leisure complex, a joint venture with CSC; a $£ 35 \mathrm{~m}$ new store by IKEA; a $£ 15 \mathrm{~m}$ Audi headquarters and training centre, a new Porcelanosa store and the Titanium Business Park. ${ }^{4}$ Some 2,000 new dwellings are being built nearby and proposals for other housing developments have also been stimulated. Since a number of these elements formed parts of the overall scheme that included the shopping centre, and were developed by CSC or its development partners, it is difficult to attribute all this development directly to the initial stimulus provided by Braehead. Without the infrastructure and public transport improvements that Braehead brought, it is, however, difficult to see that the business park would have been developed or that international knowledge-based firms such as ICL/Fujitsu would have been attracted as initial occupiers. Indeed, one of these IT firms noted that 'Braehead is one of the most vibrant areas in Glasgow's 
economic regeneration landscape. We're very proud to be one of the first wave of IT services companies to relocate to Braehead and we hope that our move will act as a catalyst and attract further investment in the area. ${ }^{25}$

Similarly, since the opening of the MetroCentre in 1986, on what was then derelict land, an extensive range of other developments have occurred on adjoining sites. These include a Marriott Hotel, an Asda supermarket, IKEA furniture store, two retail parks and significant amounts of high-quality riverside offices in the Watermark scheme. The importance of the MetroCentre in the location decision of these predominantly retail developments was confirmed in press reports concerning the development of the IKEA store in 1991. These quoted company sources as identifying the principal factors for locating on this site as the proximity to the A1, the availability of free car-parking and, because 'the MetroCentre already attracts millions of visitors each year which IKEA will be able to take advantage of. ${ }^{26}$

Lakeside had the same effect. From the late 1980s onward, the area immediately around that centre continued to attract a range of major retail and leisure developments. These included large IKEA and B\&Q units, a multiplex cinema, the Lakeside Arena (a large events facility), a bingo hall and a hotel. More recently, Danish furniture chain Ilva has opened a new store nearby. ${ }^{27}$ From discussions with local business groups, it is likely these developments selected this location as a consequence of the high visitor numbers and prominence of the shopping centre.

Regional Guidance for the South East (RPG9) recognised that the Bluewater Park RSC along with other Thames Gateway developments, is 'already acting as a catalyst for improving the Gateway's image thereby attracting further inward investment.' Other sources acknowledge Bluewater's role as a leading shopping centre has helped promote Kent Thameside to developers, businesses, inward investors and migrants. ${ }^{28}$

Of course, some development may well have occurred eventually in these areas even if the RSCs had not been developed. This is particularly the case at Cribbs Causeway, which was already an established location for retail warehouse and distribution uses. Again, without the Lakeside centre, some derelict land in the area may have continued to be developed sporadically with a mix of retail warehouse and distribution activity. Many of these locations had, however, been ones where no interest had been shown for many years and high remediation costs would have been a deterrent to many development schemes. There is no guarantee that any such development would have proceeded on the same scale or at the same pace. Indeed, without the catalyst of such a large landmark investment, there is no certainty that anything generating more jobs or better quality jobs would have emerged.

There is only limited evidence that RSCs have had a strong influence on locational decisions by other forms of inward investors, such as largescale manufacturing or business services. While good shopping and leisure facilities form part of the 'quality of life' factors that can bring firms to an area, other factors tend to be more important. The good transport infrastructure and services that RScs put in place can, however, 
be significant in such decisions, as new office schemes near Braehead, Merry Hill and the MetroCentre suggest. It is also noticeable that promotional material aimed at inward investors by various UK regions emphasises major shopping centres as strengths of their area. ${ }^{1-4}$ Perhaps significantly, Scottish Enterprise, in promoting different areas of Scotland as locations for new investment, lists the Braehead Centre, along with Glasgow Airport, as two key features in the profile and quality of life attractions of Renfrewshire.

\section{EFFECTS ON TOURISM}

Shopping is recognised as one of UK's most popular leisure activities and its importance in tourism terms is reflected in the numbers of domestic day trips to which it gives rise. Some 16 per cent of day trips out in the UK are to go on non-regular/non-convenience shopping trips, and form the highest leisure activity after eating out or visiting friends and relatives. Surveys of tourists to Essex found that shopping centres were by far the most popular destination that visitors planned to visit, with 42 per cent of all visitors compared to 26 per cent for seaside attractions (Figure 6). The average spend per tourism day trip is almost $£ 28$ per head of which 24 per cent is spent on food, 19 per cent on clothes and 11 per cent on gifts/souvenirs. ${ }^{29}$

The RSCs are large attractors of day visitors, a significant proportion from outside their local area. The MetroCentre, for example, has attracted an average of 25 million visitors a year, Braehead 20 million and Lakeside almost 24 million. Typically, between one quarter and one-third of these visitors originate from outside the local sub-region. Lakeside, for example, attracts as many as 1,000 long distance coach trips annually from as far as Wales, the North West and Humberside, while Braehead attracts visitors from Northern Ireland.

The tourism role of the RSCs is aided by the fact that most have leisure elements or visitor attractions within or immediately adjoining them, often facilities that have established there to draw on the large numbers of shoppers visiting the site. Lakeside contains one multiplex cinema while Cribbs Causeway has the Venue leisure complex beside it. Braehead contains an ice

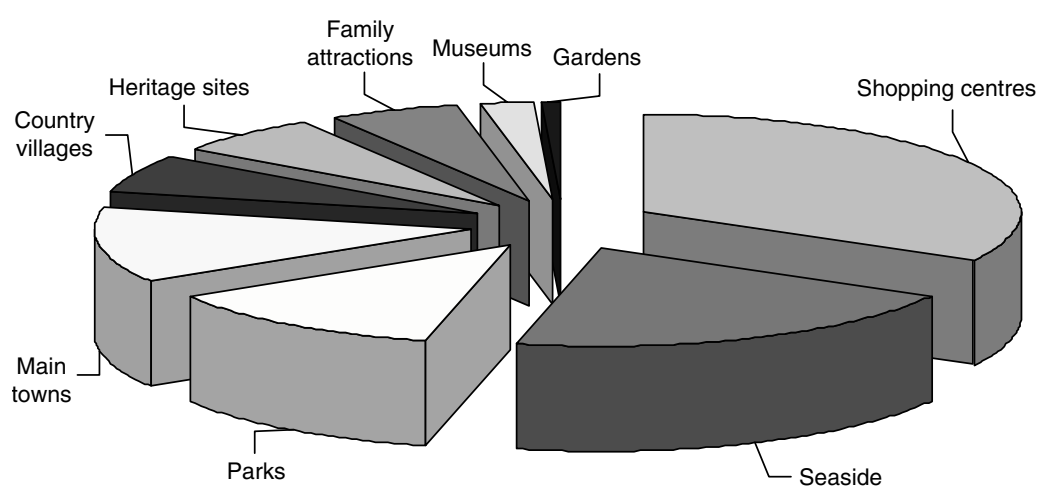

Figure 6: Planned destinations of day visitors to Essex.

Source: Essex Tourist Profiling Study, 2002 
skating complex and conference facility and has a Snowdome indoor skiing facility and museum immediately beside it. The MetroCentre contains an indoor theme park, a cinema and bowling venue.

Local and regional tourism bodies have indicated that the RSCs can help raise the tourism profile of an area by giving it a widely recognised landmark and a reason for a visit. This particularly applies to areas previously perceived as unattractive or in industrial decline, helping transform their image to one of modern facilities and attractions. The shopping centres complement other flagship visitor attraction projects of an area although this factor may be less strong than in the past when RSCs were a novelty.

For many areas, attracting short break trips is a key element of their tourism strategy and shopping has been identified as one of the main factors attracting such visitors. Glasgow, for example, markets its City shopping packages throughout the UK and abroad. In this context, the significance of the RSCs as tourist attractions is evident from the extent to which they are used by tourism bodies in promotional material. They tend to feature heavily in brochures of tourism bodies, airlines, ferry operators, hotels and coach companies.

The shopping centres are also used in targeted tourism marketing to certain countries and have been an important factor in drawing visits from some European locations. For example, the MetroCentre is a focus of short break visits from Scandinavia, while the Braehead Centre helps the Glasgow area attract some 200,000 visitors annually from Iceland and Scandinavian countries, who are primarily on shopping trips. Both the Stena shipping line and $\mathrm{P} \& \mathrm{O}$ Irish Sea Ferries promote Braehead as a destination for shopping day trips from Northern Ireland and these have been estimated to generate 28,000 day visitors and 19,000 overnight stays in the area. ${ }^{30}$

There is also some indication that the RSCs make a limited contribution to business tourism in their regions. This is the fastest growing sector of the tourism industry nationally and involves visitors on business trips, to conferences, exhibitions and corporate hospitality events. Business tourists are, on average, higher spenders than leisure visitors and business visitors often return to an attractive venue as leisure tourists. An estimated 90 per cent of arranged conference itineraries have a shopping element, and this reflects demands by delegates and their partners. Attractive shopping facilities nearby can therefore form one of a number of factors that help an area win a particular conference.

There is also some evidence that visitors to RSCs form a significant proportion of the trade of local hotels, particularly at weekends. Surveys found that between 80 and 90 per cent of weekend guests between October and December to some hotels near the MetroCentre were staying specifically to undertake a shopping trip there, and many of these returned on an annual basis.

\section{IMPACTS ON OTHER CENTRES}

It has long been a concern that the retail success of the RSCs has adversely affected town centres in the surrounding area. Government 
guidance in PPS6 notes that new out-of-centre regional or sub-RSCs have a substantial impact over a wide area and can harm the vitality and viability of existing centres within their catchments.

It is possible to explore the extent of any such impact by reviewing various indicators of retail health and economic change over time in town centres surrounding the regional centres. Suitable indicators include retail rents, retail yields, retail rankings, and changes in retail employment, levels of retail vacancy, and numbers and types of retail units (Figure 7). A further useful guide is evidence of major new retail developments or investments in a town centre, changes in the general extent of the centre or loss of any key retailers. Discussions with the relevant town centre managers also provided qualitative views on impacts.

The research underlying this paper examined ten or more town centres surrounding each of the four RSCs, selected in terms of factors such as proximity, size, their retail function and how likely they were to compete with the regional centre. This analysis did not aim to cover every possible situation of retail impact but focused on those centres most likely to have been affected based on the evidence available. It also has to be recognised that it is difficult to isolate impacts on town centres arising solely from the regional centre as opposed to other factors that can affect town centres, such as national and international economic events, general retailing trends and new developments in other competing shopping centres and out-of-centre retail schemes. For example, superstore or retail warehouse developments nearby can often have more direct impact.

Some broad conclusions can be drawn from this research over four RSCs. First, the RSCs clearly had some impact on adjoining centres but this was largely in the period shortly after the former opened. The evidence, however, suggests that the new developments have not had a long-term, detrimental impact on most of the surrounding centres. Retail indicators, where available, suggest that most of these town centres are performing generally no worse, and in some cases far better, than they were before the regional centre opened, and most centres have maintained

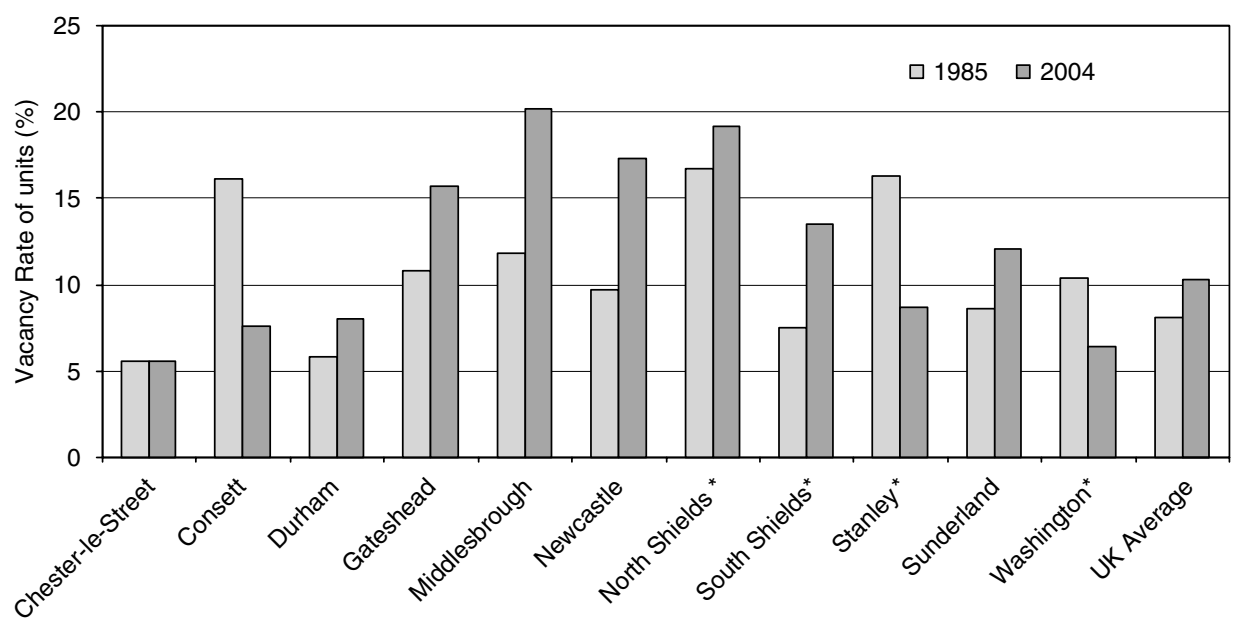

Figure 7: Change in retail vacancy in centres near the MetroCentre, 1985-2004. Source: GOAD plans * Note: base year later than 1955 
their retail function and status. There is no evidence that the RSCs examined here prevented any planned new investment taking place in nearby town centres.

Some smaller nearby centres did suffer. Gateshead, the closest town centre to the MetroCentre, initially experienced higher vacancy levels and a sharp initial fall in its retail ranking. Gateshead's shift to a local convenience destination serving a more localised catchment area had, however, been occurring over a long period, largely due to competition from Newcastle city centre the regional capital only $1 \mathrm{~km}$ away, rather than to the opening of the MetroCentre. ${ }^{31}$ Despite this, Gateshead town centre has seen modest improvement in recent years, with yields falling and improvement in its retail ranking since 1995. The centre has also increased its number of retail units and multiple retailer representation while a town centre regeneration initiative is now underway. New investment is now planned to complement the success of the Quayside regeneration nearby.

This was also broadly the case with Grays, a small centre close to Lakeside, which had high vacancy levels and slower retail rental growth after Lakeside opened. The former has now, however, consolidated its role as a convenience goods centre with major new investment from a Morrison's supermarket. This outcome is in line with the prediction, and accepted consequence, when Lakeside was originally permitted by the Secretary of State that Grays would 'continue to operate as a local centre offering a different service from that of Lakeside'.32

There were perceptions that Paisley town centre in Renfrewshire also suffered after the Braehead centre opened in 1998 and the latter may well have played some part in this decline, or hindered that centre moving forward. Paisley had, however, been affected by a range of other factors and was not in strong health prior to Braehead opening. Also, Braehead did not prevent new investments in Paisley taking place that had been planned prior to the larger centre's opening. Various initiatives are underway to help the town centre develop an altered role. ${ }^{4}$

Overall, the RSCs did not prevent ongoing investment and growth in most of the town centres examined. In several cases, such centres were found to have experienced greater effects from retail improvements in other nearby town centres than from the RSC. These developments, along with other forms of retail improvement, are part of widespread changes in retailing over the past 20 years.

There are also indications that the RSCs have stimulated major improvements within some surrounding town centres, leading to increased competitiveness or redefining of their role. This included new retail investment as well as public realm improvements. This appears to have been the case with Newcastle and Bristol city centres in response to the MetroCentre and Cribbs Causeway Mall respectively, and with Dartford town centre to counter the expected effects of Lakeside and Bluewater Park.

Other research suggests that those town centres which responded best to changing consumer (and business) expectations survived better. Newcastle city centre, for example, has always responded actively to the development of competing centres — the MetroCentre in particular. 
New traffic management, car parking, shopping centre development and many other responses, in a climate of private-public sector collaboration, meant that adverse impacts from a strong new competitor were relatively short-lived. ${ }^{33}$

The broad conclusion which can be made from this analysis is that the RSCs analysed in this research had some impact on adjoining centres in the period after they opened but that such impacts were generally short-lived and in some cases stimulated new investment in the affected centres. While a few smaller centres were affected, other factors and longer term problems played a significant part, and the regional centres have stimulated a rethink of the formers' roles. Initial impacts now appear to have stabilised, then new improvements occurred; at the same time the regional centres have become assimilated into the regional retail hierarchy.

\section{WIDER COMMUNITY ROLES}

The RSCs also appear to have brought some less tangible economic effects and some benefits to the communities in which they are located. Most obviously, they provide a range and mix of shopping and leisure facilities similar to that often found in city centres and give local communities a much higher level of shopping provision than their local area would otherwise have supported.

Again, the significant concentration of shopping and leisure facilities, with high visitor numbers, tends to support a higher level of public transport provision for longer hours than would otherwise exist within the local area. Some of these centres now contain a high level of public transport infrastructure and have achieved a high degree of modal shift. In areas where the aim has been wider regeneration and creation of sustainable communities, this high-quality shopping provision and public transport make the area a more attractive place for people to want to come to live and work, and helps attract new residential and business occupiers, in turn helping to produce a vibrant and mixed community.

Partly because of their high profile landmark buildings, their range of leisure and other facilities, and the good public transport they support, the RSCs often form a widely recognisable and easily accessible facility with an environment that forms a natural focal point for the local community. As such, they tend to be used to host community and business events, trade exhibitions, recruitment fairs and youth events. In addition, they frequently accommodate recruitment and training services (Figure 8). For example, the 'MetroPeople' training centre within the MetroCentre, funded by Jobcentre Plus, offers work skills training to local residents, while the MetroJobs service functions as a drop-in centre, designed to be more readily accessible and better oriented to the different groups it serves compared to a traditional job centre. ${ }^{34}$

Turning to wider economic considerations, the regional centres provide a substantial amount of modern, purpose-built retail premises of varying sizes, in a single location. These benefit from good servicing facilities and vehicular access, enabling efficient delivery which minimises the need for on-site space for storage of goods. The premises are in single-ownership, allowing for efficient management. There is also evidence that their initial retail competition effects has stimulated new investment and other 


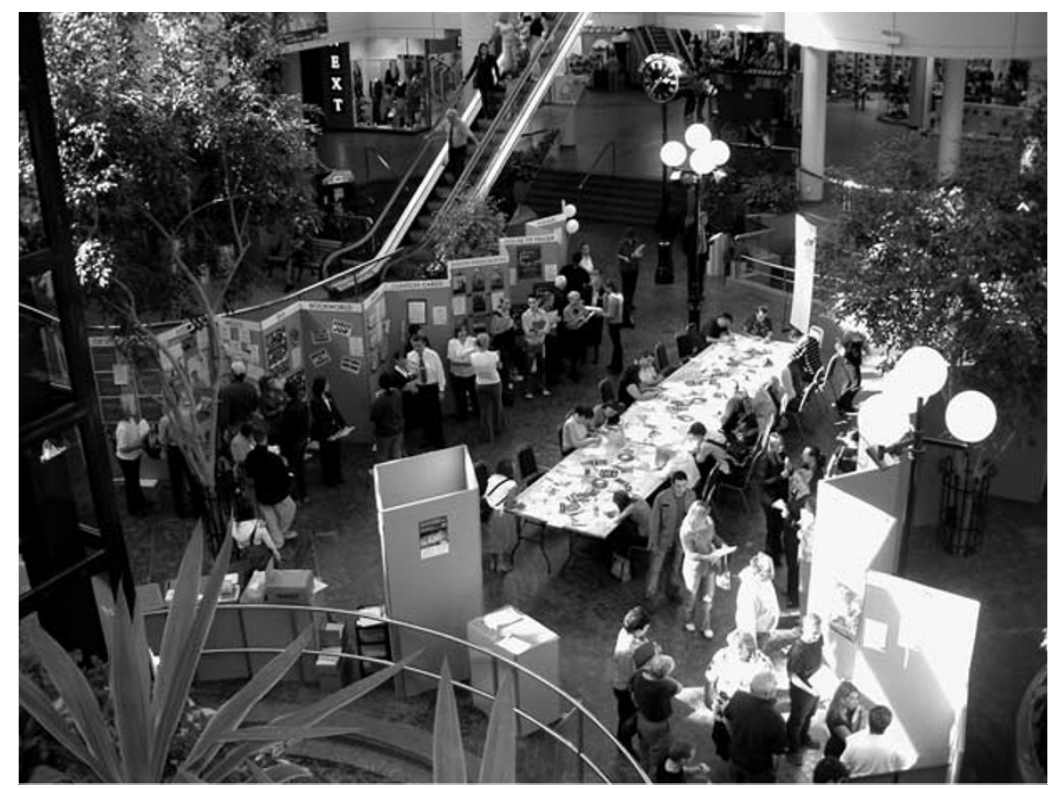

Figure 8: Job Fair event held at MetroCentre in 2003

improvements to town centres in the surrounding area, or forced them to consider their retail role. In general, these factors should produce long-term benefits in the competitiveness of retailing in the area, and indirectly to regional economic competitiveness.

There are also some suggestions that RSCs have encouraged and enabled innovation by retailers (for example in larger stores or different styles of display), have stimulated improvements in retail productivity (in more efficient use of more modern space and facilities) and have changed supply chains (with different concentrations of buyers in different places), but there is little hard evidence.

\section{CONCLUSIONS}

RSCs are now an established and important part of the economy. They are part of the restructuring of the system of retail provision over the last 30 years in the UK, as well as a reflection of retail innovation that occurred to meet changing consumer demands. Their impact on shopping also needs to be seen in context - they account for only 2-3 per cent of total retail sales, compared with the 40 per cent or so taken by large food stores and retail warehouse parks.

RSCs are big players in their regional economies and create a significant number of jobs and wealth in the local areas they lie within, the benefits of which are rarely highlighted; instead the focus has been on their apparent negative impacts despite the lack of evidence to substantiate the positions adopted. In some cases, the RSCs have given a clearer identity to an area, and helped change perceptions of it. Their role in stimulating new development of derelict and unattractive areas, and in attracting other investment to areas that had been previously less successful in that regard, has also been important.

As expressions of modern retailing, RSCs have made their contribution to this overall growth in opportunity, but they have been 
additionally effective - because of the size, scope and character in providing large numbers of local jobs for local people, in ways that prestige projects in other sectors (such as office development, for example) have often been unable to match. RSCs have worked with employment, regeneration and education agencies to provide training and development opportunities for these groups. With many RSCs located in areas of existing high unemployment, such contributions have been particularly effective.

Their impacts on nearby town centres have been variable, depending on the health and strength and innovation capacity of surrounding centres, and the state of the consumer economy. Those which responded well to changing consumer expectations have fared best, while the new competition they provided has, in some cases, stimulated improvements and investments in other centres. Earlier concerns on their potential adverse effects on town centres have not been fully realised in most cases.

Looking ahead, what is the future of RSCs? No new centres have been permitted since the early 1990 s and the recent planning climate has meant any further regional centres are highly unlikely. At the same time, the recent Barker Review of the Planning System gave some glimmer of hope that views on out-of-centre retailing may be shifting.

There is a need for a more considered and informed discussion about the future of the existing RSCs. This is starting to happen with plans and policies emerging for the areas around Brent Cross, Merry Hill, Braehead, MetroCentre and Lakeside. As an example, the Kent \& Medway Structure Plan recognises that 'the planning and development strategy in North Kent will result in Bluewater becoming a major centre for retail, leisure and entertainment embedded within the new urban area of Kent Thameside'. A new community of 650 homes is being developed immediately north of Bluewater, and Eastern Quarry to the east is allocated for 7,250 new homes.

Most of the RSCs were justified on the back of their potential regeneration benefits. Their strengths and attractiveness stems from a number of characteristics that mean they are ideally suited to drive a new wave of regeneration around them. Good road and public transport infrastructure, a wide range of shops, leisure and community facilities, and availability of development land around them - these are ingredients that can and should lead to the emergence of RSCs as focal points for sustainable new mixed use communities. It is for the relevant local authorities and regional assemblies (in partnership with RSC owners) to seize the initiative and embrace a new positive agenda for the future of RSCs in plan-making activities.

\section{Acknowledgements}

We acknowledge the valuable inputs to this research of the Oxford Institute of Retail Management at the Said Business School, Oxford.

\section{References}

1. Nathaniel Lichfield \& Partners Ltd. (2005). Economic impact of the MetroCentre, Company report for Capital Shopping Centres.

2. Nathaniel Lichfield \& Partners Ltd (2005). Economic Impact of the Lakeside Regional Shopping \& Leisure Centre, Company report for Capital Shopping Centres. 
3. Nathaniel Lichfield \& Partners Ltd (2006). Economic Impacts of the Cribbs Causeway Regional Shopping Centre, Company report for Capital Shopping Centres.

4. Nathaniel Lichfield \& Partners Ltd (2006). Economic Impacts of the Braehead Regional Shopping Centre, Company report for Capital Shopping Centres.

5. Extensive analyses of different kinds of trips to regional shopping centres can be found in Roger Tym \& Partners (1994). The Merry Hill Extension, a Retail Impact Study for Chesterfield Plc, Roger Tym \& Partners, London; and Howard, E.B. \& Davies, R.L. (1993). The Impact of Regional out-of-town Retail Centres: The case of the Metro Centre. Pergamon Press, London.

6. For example: Lowe, M.S. (2000). Britain's regional shopping centres: new urban forms? Urban Studies. 37(2), 261-274.

7. Schiller, R. (1986). The coming of the third wave. Estates Gazette, 16th August.

8. Davies, R.L. (2004). Planning policy for retailing, in Reynolds, J., Cuthbertson, C. (eds.), Retail Strategy: The View from the Bridge, Elsevier, Oxford.

9. Northavon District Council. Application by JT Baylis and Co Ltd. Inspector's Report on Public Inquiry December 1989-January 1990, and Secretary of State's letter November 1991.

10. Scottish Executive Development Department (2004). Research Study on the effectiveness of NPPG8: Town centres and retailing, Scottish Executive, Edinburgh, p. 43.

11. Centre for the Study of Retailing in Scotland (2004). Economic Impact of the Braehead Shopping \& Leisure Centre.

12. Regeneris Consulting (2006). Economic impact of the expansion of Brierly Hill/Merry Hill, available from http://www.blackcountryconsortium.co.uk/old/download.asp?fileid=299\& detailsid $=106$.

13. Based on information supplied by Management of CSC regional shopping centres, 2004-2006.

14. Gateshead Metropolitan Borough Council (1989). MetroCentre Employment Survey.

15. English Partnerships (2004). Additionality Guide, available from http://www. englishpartnerships.co.uk/docdownload.aspx?doc=C799363E2FFF45B789F70168169EBEE8. pdf\&pid=64241OphaK9K2AAJhl51wMwRzZ4YhYXY.

16. Centre for the Study of Retailing in Scotland (2004). Economic Impact of the Braehead Shopping \& Leisure Centre.

17. Bremner, P. (2003). Employment study of Braehead Shopping Centre for the Centre for the Study of Retailing in Scotland.

18. Office for National Statistics (2007). Quarterly Labour Force Survey, September-November 1997. Office for National Statistics, London.

19. Based on discussions held with Braehead Recruitment Desk, October 2005.

20. Jobcentre Plus press release, 5th February, 2003, 'Nick Brown goes shopping for jobs in Gateshead'.

21. Pavey, M. (2004). Unemployment in Thurrock 2003. Thurrock Council Economic Development, available from http://www.thurrock.gov.uk/i-know/pdf/unemployment_2003.pdf.

22. Gateshead Metropolitan Borough Council (1997). MetroCentre Information Note, 4th edn, 1997

23. Smyth, H. (1994). Marketing the City: The Role of Flagship Developments in Urban Regeneration. E.\&.F.N.Spon, London.

24. Tyne \& Wear Research and Information (1998). Economic Trends in Tyne \& Wear - A Ten-Year Review, available from http://www.newcastle.gov.uk/TWRI.nsf/0/ cb8b2be72a64ecd680256957002efa87/\$FILE/ET98.pdf.

25. Director ICL, Scotland Quote in Scotland International, News for International Business \& industry, Autumn 2001.

26. 'Swedish style', Article in Newcastle Evening Chronicle, 21st August, 1991.

27. Article in Times, January 2005.

28. Kent County Council 2006, Draft, Technical Note No. 2, Town Centres, March.

29. The GB Leisure Day Visits Survey 2002/03 is a survey undertaken by the Countryside Agency, Countryside Council for Wales, British Waterways, Department for Culture, Media and Sport, Environment Agency, Forestry Commission, Scottish Natural Heritage, VisitBritain, VisitScotland, and Wales Tourist Board.

30. Dawson, J. \& Taylor, M. (2003). Economic Impact of the Braehead Shopping \& Leisure Centre on the Surrounding Region, Perceptions \& Reality.

31. DTZ Debenham Thorpe/Nathaniel Lichfield \& Partners (1996). Town Centre Futures: The Long Term Impacts of New Developments, BCSC Research Report.

32. Secretary of State decision letter on Lakeside Regional Shopping Centre, April 1987.

33. Davies, R. \& Howard, E.B. (1989). The Metro Centre Experience - And the Prospects for Meadowhall. International Journal of Retail \& Distribution Management. 17(3).

34. Based on discussions with MetroJobs, November 2004. 